
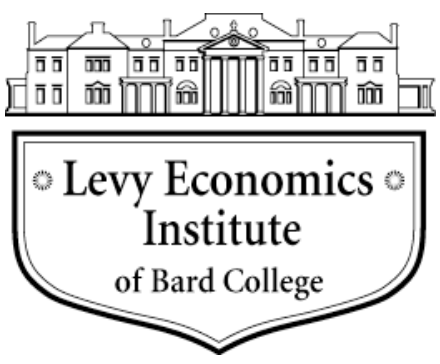

Working Paper No. 777

\title{
A Simple Model of Income, Aggregate Demand, and the Process of Credit Creation by Private Banks*
}

\author{
by \\ Giovanni Bernardo \\ University of Pisa and New Economics Foundation \\ Emanuele Campiglio \\ Grantham Research Institute, London School of Economics
}

October 2013

\begin{abstract}
* We would like to thank Victoria Chick, Jesus Crespo Cuaresma, Nick Edmonds, Graham Hodgson, Andrew Jackson, Steve Keen, Jo Michell, Josh Ryan-Collins, Stefan Speck, and the whole Money and Credit group at University College London for their valuable comments and suggestions. All remaining errors are our own. This project was funded by the New Economics Foundation. Correspondence:

giovanni.bernardo@neweconomics.org; e.campiglio@1se.ac.uk
\end{abstract}

The Levy Economics Institute Working Paper Collection presents research in progress by Levy Institute scholars and conference participants. The purpose of the series is to disseminate ideas to and elicit comments from academics and professionals.

Levy Economics Institute of Bard College, founded in 1986, is a nonprofit, nonpartisan, independently funded research organization devoted to public service. Through scholarship and economic research it generates viable, effective public policy responses to important economic problems that profoundly affect the quality of life in the United States and abroad.

Levy Economics Institute P.O. Box 5000

Annandale-on-Hudson, NY 12504-5000

http://www.levyinstitute.org

Copyright (C) Levy Economics Institute 2013 All rights reserved 


\begin{abstract}
This paper presents a small macroeconomic model describing the main mechanisms of the process of credit creation by the private banking system. The model is composed of a core unit — where the dynamics of income, credit, and aggregate demand are determined - and a set of sectoral accounts that ensure its stock-flow consistency. In order to grasp the role of credit and banks in the functioning of the economic system, we make an explicit distinction between planned and realized variables, thanks to which, while maintaining the ex-post accounting consistency, we are able to introduce an ex-ante wedge between current aggregate income and planned expenditure. Private banks are the only economic agents capable of filling this gap through the creation of new credit. Through the use of numerical simulation, we discuss the link between credit creation and the expansion of economic activity, also contributing to a recent academic debate on the relation between income, debt, and aggregate demand.
\end{abstract}

Keywords: Banking System; Credit Creation; Growth; Aggregate Demand; Macroeconomic Modeling

JEL Classifications: E20, E51, G21, O42 


\section{INTRODUCTION}

The absence of money, credit and the banking system from the overwhelming majority of macroeconomic models has been cited as a major failure of the economic discipline in the aftermath of the financial crisis. Not only were economists unable to "predict" the crisis and the subsequent recession - with some exceptions, see Bezemer (2009) - but they also seemed incapable of properly comprehending its mechanisms and helping policy-makers to deal with sluggish economic activity, high unemployment and soaring deficit levels.

This shouldn't come as a surprise. For long decades the tendency of conventional economic theory has indeed been to disregard many of the macroeconomic variables that played a major role in the development of the crisis, such as money, debt and credit. Despite being the most important actor in creating credit in modern economies, as we will explain in Section 2.1, the private banking system has been systematically excluded from macroeconomic models, even those used by major central banks for forecasting and policy analysis (Brayton and Tinsley, 1996; Harrison et al., 2005; Dieppe et al., 2011). The omission has caused the discipline to overlook some of the most worrying economic trends of the past decades - the exponential increase in private debt levels, for instance - and to arrive ill-prepared for the financial crisis.

However, this seems to be changing in recent years. The gravity of the situation has led many - in governments, universities and civil society - to seek for alternative economic strategies and new analytical tools. Building on a long (although minoritarian until recently) tradition of research (Schumpeter, 1934; Minsky, 1982; Moore, 1988; Godley and Lavoie, 2012) the discipline is currently in the process of interrogating itself over how to include banking and credit in macroeconomic theory and many researchers have started building models where their role in shaping the wider economy is explicitly recognized (Keen, 1995; Godley and Zezza, 2006; Binswanger, 2009; O'Sullivan and Kinsella, 2011; Bezemer et al., 2012; Benes and Kumhof, 2012; Yamaguchi, 2013).

We intend to contribute to this literature by presenting a relatively simple but original macroeconomic model aimed at describing the main mechanisms of the process of credit creation by the private banking system. The model is composed of two main parts: 
- A "core" unit, where the main dynamic mechanisms of income, debt and aggregate demand are sketched. In order to grasp the role of credit on the functioning of the economic system we make an explicit distinction between planned and realized variables, thanks to which, while maintaining the ex-post accounting consistency, we are able to introduce an ex-ante wedge between current income and planned expenditure. Private banks are the only agents capable of filling this gap through the creation of new credit.

- A set of sectoral accounts that represent the agents populating the economy: non-financial firms, banks, central bank, households and gilt sellers. Although not relevant for the determination of the economic dynamics, the additional variables introduced in this part are crucial to ensure the stock-flow consistency of the model.

Despite its analytical simplicity, the model is able to grasp the crucial features of the credit creation mechanics, and its strong connection to the expansion of economic activity: a confident banking system, willing to grant credit to firms for productive investments, is a necessary prerequisite for the economy to prosper.

The remainder of the paper is organized as follows. Section 2 presents the motivation of the paper and the related literature, focusing in particular on the role of the banking system in creating credit. Section 3 describes the theoretical structure of the core model, analyzes the properties of its dynamics and shows some numerical simulations. Section 4 presents the full stock-flow consistent model introducing the balance sheets of agents populating the economy. Section 5 offers some numerical simulations to show how our model reacts to shocks in some key parameters. Finally, Section 6 concludes and discusses future research.

\section{MOTIVATION AND LITERATURE}

\subsection{The endogenous nature of money}

The model has two main conceptual foundations:

1. In modern economies private banks are the only economic agents, together with central banks, capable of creating new money, specifically in the form of credit;

2. They do so autonomously, without responding to the control of a central bank, or at least not as this is understood in the traditional money multiplier theory. In other words, money is endogenous. 
The first claim is quite straightforward once the appropriate definition of money is used. The confusion on the subject is usually due to the fact that there exists no unique definition of money. A set of monetary aggregates are instead used, which differ according to their degree of liquidity - that is, how easily they can be exchanged in the market. The classification of monetary aggregates differs across countries, but in general the narrowest monetary aggregates represent the "monetary base", which includes the most liquid monetary assets such as central bank reserves and physical cash (notes and coins), while the broader aggregates gradually include less liquid means of payment, such as deposits and other funds.

For simplicity, we can assume the existence of two main types of monetary asset:

- Narrow money, composed by central bank reserves (no physical cash exists in our model). Reserves are deposits that private banks hold at the central bank, in the same way as households and firms hold accounts at private banks.

Reserves are created by central banks themselves, and don't need to be backed by any "physical" values.

- Broad money, equal to the stock of deposits held by households, firms and other economic agents. Broad money is an extremely important variable as it represents the overall amount of credit existing in the economy. Credit can be exchanged for goods and services and is increasingly used as a means of payment in modern societies. Credit is created by private banks: every time that a bank grants a loan it simultaneously creates a corresponding deposit, that can then be used and transferred to purchase goods and services. That is, banks are capable of expanding their balance sheets by creating new credit, as the following quotation by the Bank of England also states:

"By far the largest role in creating broad money is played by the banking sector (..) When banks make loans they create additional deposits for those that have borrowed." (Berry et al., 2007)

Textbook economic theory presents an explanation of credit creation based on the IS-LM framework and the money multiplier theory, according to which central banks are able to change the quantity of credit existing in an economy by adjusting the amount of their reserves (Blanchard and Johnson, 2012). We here argue that the 
money multiplier theory is faulty, for a variety of reasons. First of all, central banks have been using interest rates as their main monetary policy tool, not monetary aggregates (Romer, 2000). But even leaving this aside, the assumption that central banks are able to control the quantity of credit created by private banks through the manipulation of reserves appears to be incorrect (Keen, 2001; Werner, 2005; RyanCollins et al., 2012).

We prefer to adopt instead a different interpretation of the mechanisms of credit creation, usually referred to as endogenous money theory (Lavoie, 2003). In a nutshell, the theory argues that first private banks decide how much credit to create - that is, how many loans to grant - independently of how many reserves they have, and then, in a second moment, they ask for reserves from the central bank. Unless the central bank wants to create a credit crunch and a financial crisis, the demand for reserves by the private banking system will be satisfied. The causation process is thus completely reversed with respect to the money multiplier theory.

Figure 1: Dynamics of narrow (M0) and broad money (M4)

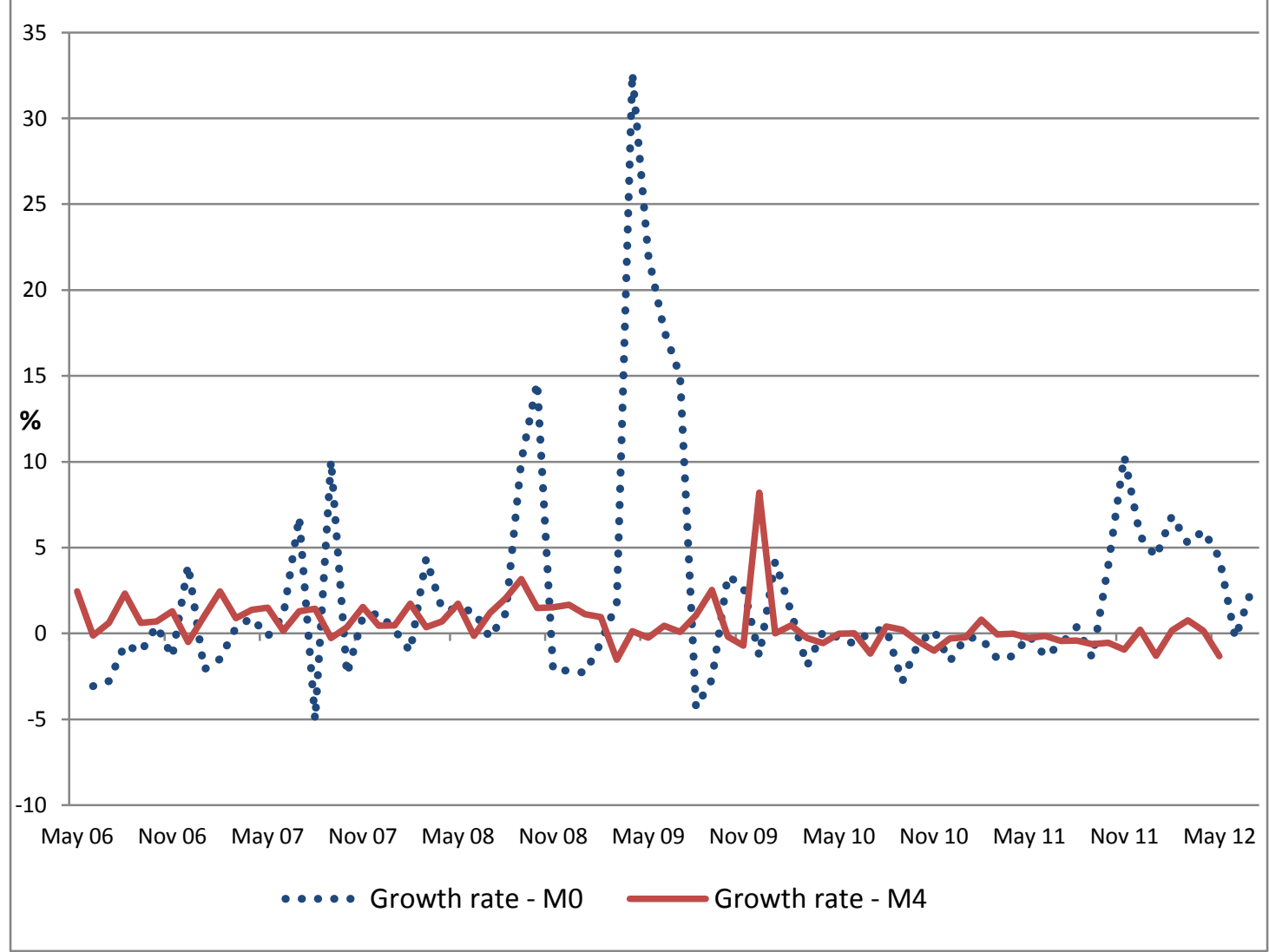

(Source: Bank of England) 
The endogenous nature of money seems to be well known and accepted by central bank economists ${ }^{1}$ (Goodhart, 1984) and confirmed, among others, by the Bank of England operational framework ${ }^{2}$ :

(F)or each reserves maintenance period (..) the Monetary Policy Committee sets the reserves remuneration rate (Bank Rate) and each scheme participant sets a target for the average amount of reserves they will hold, taking into account their own liquidity management needs (Bank of England, 2012a)

Further evidence in support of our approach has come from the recent monetary policies put in place to restore confidence after the crisis and promote growth. Unable to reduce interest rates, already close to zero, the Bank of England and the US Federal Reserve - and, although in a slightly different way, the European Central Bank - have started "unconventional" monetary policy measures called Quantitative Easing (QE). Quantitative easing involves an expansion of the central bank balance sheet. Two simultaneous events thus take place: the central bank buys government or corporate bonds from the secondary market and correspondingly increases the amount of reserves.

Figure 2: Rate of approval of demand for loans

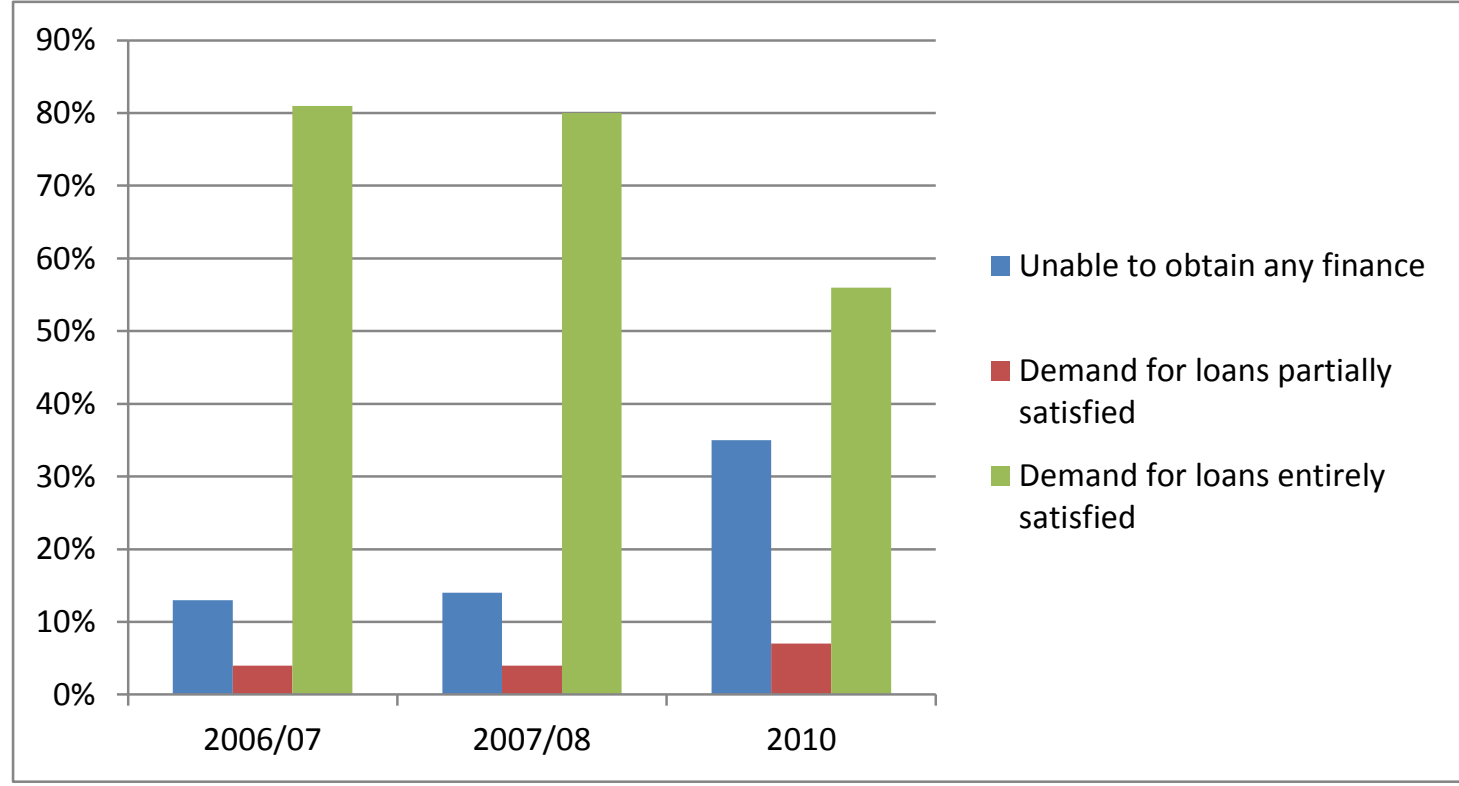

(Source: BIS, 2011)

\footnotetext{
${ }^{1}$ Mervyn King, former Governor of the Bank of England, recently stated: "When banks extend loans to their customers, they create money by crediting their customers' accounts. The usual role of a central bank is to limit this rate of money creation, so that an excessive expansion of money spending does not lead to inflation." (Bank of England, 2012b)

${ }^{2}$ The framework based on target reserves has been recently suspended, as the Quantitative Easing policies led to the creation of an amount of reserves much higher than the one banks would have chosen.
} 
According to the standard theory based on the money multiplier QE measures should have had the effect of expanding the amount of broad money, but such a claim is not supported by the empirical evidence. As Figure 1 shows for the UK, the overall amount of credit in the economy (M4) didn't seem to be affected by the expansion of the Bank of England reserves (M0).

The most crucial variable in determining the dynamics of the money supply seems instead to be the level of confidence that the banking system has in the ability to repay of debtors and, more generally, in the performance of the economic system. If private banks are confident they will be willing to expand broad money by granting a large amount of loans. If, instead, the banking system is frightened and worried about the stability of the economy system, banks just won't lend, irrespective of the amount of reserves that the central bank creates.

Unfortunately, the confidence of the banking system is a variable quite difficult to properly define and measure. A possible proxy could be the "approval rate" of the demand for credit, i.e. the proportion of loans applications accepted with respect to the total demand for credit. Figure 2 reports some data from a UK survey on small and medium enterprises (BIS, 2011): since 2006/07 in the UK the proportion of the demand for loans that has been entirely satisfied has dramatically decreased. As before the crisis the rate of the demand for loans that was entirely satisfied was around $80 \%$; in 2010 this rate had dropped to approximately 55\% and simultaneously the rate of firms who were refused credit increased to almost $40 \%$ of the total. We will show the effects of such a drop on our model economy in Section 5. 
Figure 3: The process of credit creation

\begin{tabular}{|c|c|}
\hline \multicolumn{2}{|c|}{ Private Banks } \\
\hline Assets & Liabilities \\
\hline+100 & +100 \\
(Loans) & (Firms \\
& Deposits) \\
\hline & +10 \\
+10 & (Gilt \\
(Reserves) & sellers \\
& Deposits) \\
\hline
\end{tabular}

\begin{tabular}{|c|c|}
\hline \multicolumn{2}{|c|}{ Gilt sellers } \\
\hline Assets & Liabilities \\
\hline $\begin{array}{c}\text { (Deposits) } \\
\text { (10 }\end{array}$ \\
\cline { 1 - 1 }-10 \\
(Gilts) \\
\end{tabular}

\begin{tabular}{|c|c|}
\hline \multicolumn{2}{|c|}{ Central Bank } \\
\hline Assets & Liabilities \\
\hline+10 & +10 \\
(Gilts) & (Reserves) \\
\hline
\end{tabular}

\begin{tabular}{|c|c|}
\hline \multicolumn{2}{|c|}{ Non-financial firms } \\
\hline Assets & Liabilities \\
\hline+100 & +100 \\
(Deposits) & (Loans) \\
\hline
\end{tabular}

\subsection{The process of credit creation by private banks}

The model presented in this paper is built using a methodology that pays a great deal of attention to its accounting consistency, typical of stock-flow consistent models (Lavoie and Godley, 2002; Godley and Lavoie, 2012; Caverzasi and Godin, 2013; Yamaguchi, 2013). Every agent in the economy is thus modeled using a double-entry bookkeeping representation of their balance sheets. They all have some assets (on the left-hand side) and some liabilities (on the right-hand side) that change over time. Net worth, calculated as the difference between assets and liabilities, is what makes the balance sheet balanced. In every period assets must be equal to liabilities plus the net worth and, as a consequence, total changes in assets must be equal to the total change in liabilities. In other words, any economic transaction that takes place must be recorded twice, on the asset side of an account and simultaneously on the liability side of another account. This representation turns out to be very useful in order to model financial flows in the correct way.

Keeping this in mind, and following the argumentation presented in the previous section, we can sketch what we argue is the most appropriate way of modeling the creation of credit by the banking system in Figure 3. A total of four sectors are involved in the process: the central bank, non-financial firms, private banks and a fourth agent we call "gilt sellers", which represents the gilts secondary market.

To start, suppose that a firm needs additional finance (e.g., in order to invest in 
new machinery) and asks for a loan - of 100, say - to the bank. The bank decides to approve the request and creates a new deposit for the firm. The creation of new credit expands the balance sheet of both the firm and the bank in a way that doesn't change their net wealth. The firm now has a deposit of 100 on the asset side and a debt towards the bank of the same amount on the liability side; the private bank in turn has a credit towards the firm on the asset side and the deposit on the liability side. In this way, the balance sheet of the economy has expanded, and everything is consistent, i.e. the change in assets has been equal to the change in liabilities.

At this point, supposing that banks are required to respect a reserve ratio of $10 \%$, or desire to do so, the bank asks for an increment of its reserves equal to 10 from the central bank. The central bank - which most likely doesn't wish the bank to withdraw the loan to the firm causing it to postpone the investment, or worse to fail - simply accepts the request creating the desired reserves $(+10$ on the central bank liabilities side and +10 on the private bank asset side).

To back the expansion of its liabilities, the central bank simultaneously buys an amount of gilts equal to 10 on the secondary market, here represented by the gilt sellers (typically pension funds). There is no expansion of the gilt seller's balance sheet, but rather a change in its asset composition: it sells gilts and simultaneously receives the same value in the form of bank deposits. Finally, the new deposits are recorded in the liabilities side of private banks, thus balancing the entire economy's balance sheet.

\subsection{A Debate on Income, Debt and Aggregate Demand}

Particularly relevant to our paper is a debate that has developed in early 2012 between economists Paul Krugman, Steve Keen and other researchers on the role of the banking system in stimulating aggregate demand. The discussion was sparked by a paper (Keen, 2012) in which the author argued that the net changes in the level of debt add to the economy's aggregate demand:

$$
A D=Y+\Delta D
$$

where $A D$ is aggregate demand, $Y$ is income and $D$ is the stock of debt. This statement is strongly counterintuitive, as it contrasts with the usual understanding of macroeconomic variables in which aggregate demand (defined as aggregate expenditure) is equal to aggregate income by definition. Indeed, it raised critical 
comments, most notably from Nobel laureate Paul Krugman ${ }^{3}$, who objected that at any time in a closed economy someone's expenditure must be equal to someone else's income and therefore no discrepancy exists between aggregate demand and aggregate income.

As we already argued in Bernardo and Campiglio (2012) the disagreement mainly had to do with different implicit definitions of aggregate demand: while Krugman employs the traditional ex-post definition of demand being equal to realized expenditure - what is actually spent in the economy - Keen prefers an ex-ante definition, where future expenditure plans also count for the determination of aggregate demand. In other words, both authors are right and consistent in their own logic: as Krugman states, at the end of every accounting period income must be equal to what was spent; but it's also true that during each time period economic agents formulate expectations on the future and make expenditure plans which may not be equal to their current income, as Keen argues (Bezemer et al., 2012).

The model presented in this paper can be fruitfully employed to "solve" the controversy. We do so by explicitly disaggregating planned from realized expenditure. In each time period realized expenditure is equal to aggregate income, respecting expost consistency, while planned expenditure can diverge from it. In this case, as we will show using numerical simulations in Section 3.3, the discrepancy between the two is equal to the net change in the levels of debt, which in turn depends on the willingness of the private banking system to grant loans. Our model can be seen to give an analytical representation of Hyman Minsky's position on the subject:

"If income is to grow, financial markets must generate an aggregate demand that, aside from brief intervals, is ever rising. (..) For real aggregate demand to be increasing, it is necessary that current spending plans be greater than current received income and that some market technique exist by which aggregate spending in excess of aggregate anticipated income can be financed." (Minsky, 1982).

\footnotetext{
${ }^{3}$ On March 27th, 2012, in a post of his New York Times blog titled "Minsky and Methodology (Wonkish)" Krugman writes: "Keen then goes on to assert that lending is, by definition (at least as I understand it), an addition to aggregate demand. I guess I don't get that at all. (..) I think it has something to do with the notion that creating money = creating demand, but again that isn't right in any model I understand."
} 


\section{THE DYNAMIC MODEL}

This section presents the "core" unit of the model, where its main dynamic features are determined. Although not stock-flow consistent, this can be taken as a small demandside growth model per se, devoted to analyzing the role of the creation of credit by private banks in the wider macroeconomic context. We will complete this with all the necessary equations to make it stock-flow consistent in Section 4.

We consider a closed economy in discrete time. For the moment, we can assume that the economy is populated by three types of agents: households, firms and private banks. In Section 4 we will also introduce the central bank and gilt sellers. There exists a single good which can be used for both consumption and investment purposes, as well as serving as a monetary asset.

The model can be defined as "demand-side" because we abstract from modeling the supply side. We assume that the market will be able to satisfy any amount of demand or, alternatively, we assume a service economy where output is produced if and when a demand exists for it. Although we recognize the importance of having adjustment mechanisms for production factors, an analytical focus on demand is more appropriate to analyze the current economic situation, where sluggish growth seems to be determined more by a lack of demand rather than an insufficient supply. Furthermore, introducing a supply side would unnecessarily complicate our goal of modeling the main mechanisms of the creation of credit. A relaxation of this assumption can be found in Bernardo and Campiglio (2012).

\subsection{The Theoretical Framework}

To start, suppose a certain amount of output is sold by firms at time t. Income deriving from sales $(Y)$ is distributed among workers (households) and capital owners (firms) according to some exogenous parameter representing the labour share:

$$
\begin{gathered}
W_{t}=\alpha Y_{t} \\
\Pi_{t}=(1-\alpha) Y_{t}
\end{gathered}
$$

where $W$ are wages and $\Pi$ are gross profits.

Firms are not bound to use the entire and exact amount of their profits but can instead save or, more likely, obtain additional liquidity in the form of bank credit. By 
accumulating a debt towards the banking system, in every period firms have to repay a fixed proportion of the debt already contracted

$$
D R_{t}=\frac{L_{t}}{\rho}
$$

where $D R$ is the repayment of the principal, $L$ is the stock of loans previously accumulated by firms, $\rho$ is a parameter representing the debt repayment time.

In addition, firms have to pay some interests on the stock of debt, equal to:

$$
Z_{t}=i L_{t}
$$

where $Z$ represents interests payment and $i$ is the (exogenous) interest rate on debt.

Net profits $\Pi_{t}^{n}$ at time $\mathrm{t}$ are thus defined as:

$$
\Pi_{t}^{n}=\Pi_{t}-D R_{t}-Z_{t}
$$

On the other hand, we assume that workers plan to consume an amount of goods exactly equal to their wages, without saving nor asking for loans. The same applies to the bankers, who consume the exact and entire amount of their income, which is given by the interest payments. That is:

$$
C_{t}^{p}=W_{t}+Z_{t}
$$

Consumption $C_{t}^{p}$ is planned because it represents what households (both workers and bankers) are planning to consume in the following period, and not what they consume at time $t$, which is instead determined by their consumption plans at time $t-1$. This mechanism will become clearer at the end of the section.

At this point, firms decide how many investments they would like to carry on during the following period. We model desired investments $I_{t}^{d}$ to be a function of firms' net profits:

$$
I_{t}^{d}=\eta \Pi_{t}^{n}
$$

where parameter $\eta$ represents firms propensity to invest. If $\eta=1$ firms invest the whole and exact amount of net profits $\left(I_{t}^{d}=\Pi_{t}^{n}\right)$. If $\eta<1$ firms desire to invest less than their net profits $\left(I_{t}^{d}<\Pi_{t}^{n}\right)$. In this case, firms accumulate liquidity (in our model, 
bank deposits). This should capture the phenomenon of capital hoarding. Finally, if $\eta>1$ firms desire to invest more than their current income, i.e. net profits $\left(I_{t}^{d}>\Pi_{t}^{n}\right)$. In the latter case firms seek credit from the only agents in modern economies capable of financing the gap between planned expenditure and income: private banks. The demand for loans $\left(L^{d}\right)$ is defined as the difference between desired investments and net profits:

$$
L_{t}^{d}=I_{t}^{d}-\Pi_{t}^{n}
$$

Private banks then have to decide how much credit to create for firms. We model this decision by assuming that banks satisfy a certain proportion of the demand for loans. In our model credit creation $C C_{t}$ is thus equal to:

$$
C C_{t}=\beta L_{t}^{d}
$$

where $\beta \in(0,1)$ is a parameter representing the rate of approval of the demand for loans (see also Figure 2), which we use as a proxy for the confidence level of the banking system. When banks are confident $\beta$ is closer to 1 and a higher proportion of loans demand is satisfied; when banks are less confident $\beta$ is lower and a smaller proportion of demand for loans is satisfied. We can now define planned investments $I^{p}$ as the sum of net profits and credit creation:

$$
I_{t}^{p}=\Pi_{t}^{n}+C C_{t}
$$

and planned aggregate expenditure as the sum of planned consumption and planned investments:

$$
A D_{t}^{p}=C_{t}^{p}+I_{t}^{p}
$$

Planned aggregate expenditure becomes realized expenditure only in the following period. That is, expenditure at time $t+1$, which is also equal to income in the same period, is determined by the amount of planned expenditure at time $t$ :

$$
Y_{t+1}=A D_{t}^{p}
$$

In a similar way, we can define realized consumption and realized investments as: 


$$
\begin{gathered}
C_{t+1}=C_{t}^{p} \\
I_{t+1}=I_{t}^{p}
\end{gathered}
$$

Finally, in order to close the model, we need the dynamic equation for the stock of loans:

$$
L_{t+1}=L_{t}+C C_{t}-D R_{t}
$$

\subsection{Model Dynamics}

Manipulating equations (1)-(15) it is possible to find a system of two difference equations in $L_{t}$ and $Y_{t}$ that governs the dynamics of the economy:

$$
\begin{gathered}
L_{t+1}=\left\{1-\frac{1+\beta(\eta-1)(1+i \rho)}{\rho}\right\} L_{t}+\beta(1-\alpha)(\eta-1) Y_{t} \\
Y_{t+1}=1-\frac{1+\beta(\eta-1)(1+i \rho)}{\rho} L_{t}+[1+\beta(1-\alpha)(\eta-1)] Y_{t}
\end{gathered}
$$

It can be shown that the system (16)-(17) always has an eigenvalue $\lambda_{1}$ equal to 1 (see Appendix A.1). The other eigenvalue $\lambda_{2}$ is instead equal to:

$$
\lambda_{2}=1-\frac{1+\beta(\eta-1)(1-i \rho)}{\rho}+\beta(1-\alpha)(\eta-1)
$$

According to numerical value of $\lambda_{2}$, which is a function of the set of parameter values, the system can thus be governed by two different dynamics:

- A convergence to a stationary state, if $0<\lambda_{2}<1$;

- A balanced growth path (BGP), if $\lambda_{2}>1$.

Using (18) we can define the parameter values that, everything else being equal, define the limit between the two cases. For instance, we can define:

$$
\begin{aligned}
& \eta_{g}=1+\frac{1}{\beta[\rho(1-\alpha)-1-i \rho]} \\
& \beta_{g}=\frac{1}{(\eta-1)[\rho(1-\alpha)-1-i \rho]}
\end{aligned}
$$


where $\eta_{g}$ and $\beta_{g}$ are the values of the firms propensity to invest $\eta$ and the banks confidence level $\beta$, respectively, beyond which the system is characterized by a longrun BGP with non-zero growth of income. In other words, if, everything else being equal, $\eta>\eta_{g}$ or $\beta>\beta_{g}$, the system will have a long-run positive growth rate. On the contrary, if $\eta<\eta_{g}$ or $\beta<\beta_{g}$, the system will converge to a stationary state with no growth. Finally, $\eta=\eta_{g}$, or $\beta=\beta_{g}$, identifies the case of linear growth. The economic interpretation of this proposition is straightforward. To be growing in the long run, an economy needs a high enough propensity to invest, or a high enough banking confidence level.

We can define $l_{t} \equiv \frac{L_{t}}{Y_{t}}$ as the loans-to-output ratio. Along the BGP, one must have $l_{t+1}=l_{t}=l^{*}$. It can be shown that along the BGP (see Appendix A.2):

$$
\left\{\begin{array}{l}
l^{*}=\frac{\rho \beta(1-\alpha)(\eta-1)}{1+\beta[(\eta-1)(1+i \rho)]} \text { if } \eta<\eta_{g} \\
l^{*}=1 \text { if } \eta>\eta_{g}
\end{array}\right.
$$

In the first case, in which the economy gradually converges to a stationary state, the long-run growth rate of income is equal to zero. In the second case, in which the economy grows forever along a BGP, the growth rate is equal to:

$$
g_{Y}^{B G P}=\beta(1-\alpha)(\eta-1)-\frac{1+\beta(\eta-1)(1+i \rho)}{\rho}
$$

By imposing $\Delta X=\Delta Y=0$ one can also derive some conditions regarding initial values. $Y_{0}$ and $L_{0}$. In particular, we can define a threshold value, $\psi$, beyond which the initial stock of loans - and consequently the flow of debt repayment - is too large to allow for growth:

$$
\psi=\frac{\rho \beta(\eta-1)(1-\alpha)}{1+\beta(\eta-1)(1+i \rho)}
$$


According to $L_{0}$ and $Y_{0}$ values one can thus determine the dynamic behavior of the system (see also Appendix A.3). In the convergence case $\left(\eta<\eta_{g}\right)$ there exist three possible cases:

$$
\begin{cases}L_{0}<\psi Y_{0} & \text { Growth tothe stationary state } \\ \psi Y_{0}<L_{0}<Y_{0} & \text { Recession to stationary state } \\ L_{0}>Y_{0} & \text { Collapse }\end{cases}
$$

where "Collapse" identifies a recession that leads income levels to zero.

In the BGP case, instead, one can define only two possible dynamics:

$$
\begin{cases}L_{0}<\psi Y_{0} & \text { Exponential growth } \\ L_{0}>\psi Y_{0} & \text { Collapse }\end{cases}
$$

\subsection{Numerical simulations}

After having presented the theoretical structure of the model we now proceed to simulate it numerically. We present here three different scenarios, whose parameters and initial values are reported in Table 1:

1. Convergence to a stationary state;

2. Recession to a stationary state;

3. Balanced growth path.

With respect to all the possible dynamic behaviors of the systems reported in (24) and (25) we excluded the "collapse" cases as non-meaningful. The results of the simulations are shown in Figure 4, where three variables are pictured:

- Income $Y$, which is equal to the sum of wages $W$ and gross profits $\Pi$, and by definition equal to current expenditure (the ex-post definition of aggregate demand);

- Planned aggregate expenditure $A D^{p}$, which represents the expenditure that agents today plan to carry out tomorrow, defined in Equation (11);

- Net credit creation $N C C$, equal to the difference between new credit creation and the repayment of debt:

$$
N C C_{t}=C C_{t}-D R_{t}
$$


The first scenario, shown in Figure 4a, delivers a positive but slowing growth of income that in the long run leads the system to a stationary state. The growth process is driven by the fact that in every period of the simulation planned expenditure is higher than income, meaning that the productive sector always desires to invest more than its net profits and the banking system is always willing to fill the gap between planned expenditure and current income through the creation of new credit. Planned expenditure at time $t$ will then become realized expenditure - that is income - at time $t+1$, causing an expansion of economic activity.

Table 1: Initial values and parameters

\begin{tabular}{|c|c|c|c|}
\hline & Scenario 1 & Scenario 2 & Scenario 3 \\
\hline$\alpha$ & 0.7 & 0.7 & 0.7 \\
\hline$\eta$ & 1.5 & 1.5 & 2 \\
\hline$\beta$ & 0.8 & 0.8 & 0.8 \\
\hline$\rho$ & 10 & 10 & 15 \\
\hline$i$ & $5 \%$ & $5 \%$ & $5 \%$ \\
\hline$Y_{0}$ & 100 & 100 & 100 \\
\hline$L_{0}$ & 30 & 30 & 30 \\
\hline
\end{tabular}

Positive net credit creation will also increase the total stock of debt in the economy. This in turn will increase the flows of repayment, which eventually converge to the same value of credit creation. This causes net credit creation to converge to zero in the long run and income growth to phase out.

Figure $4 \mathrm{~b}$ shows a similar scenario where the economy converges to a stationary state, but it does so through a period of recession. As shown in Table 1 the parameter values in this scenario are identical to the previous one; what changes is rather the initial value of the stock of loans ( $L_{0}$ is now equal to 70). This causes the debt repayment variable to prevail on the new creation of credit, thus leading the planned expenditure to be, despite the same propensity to invest of entrepreneurs, lower than the current income. Net credit creation is thus negative, and converges to zero from below. 
Figure 4: Three possible model dynamics

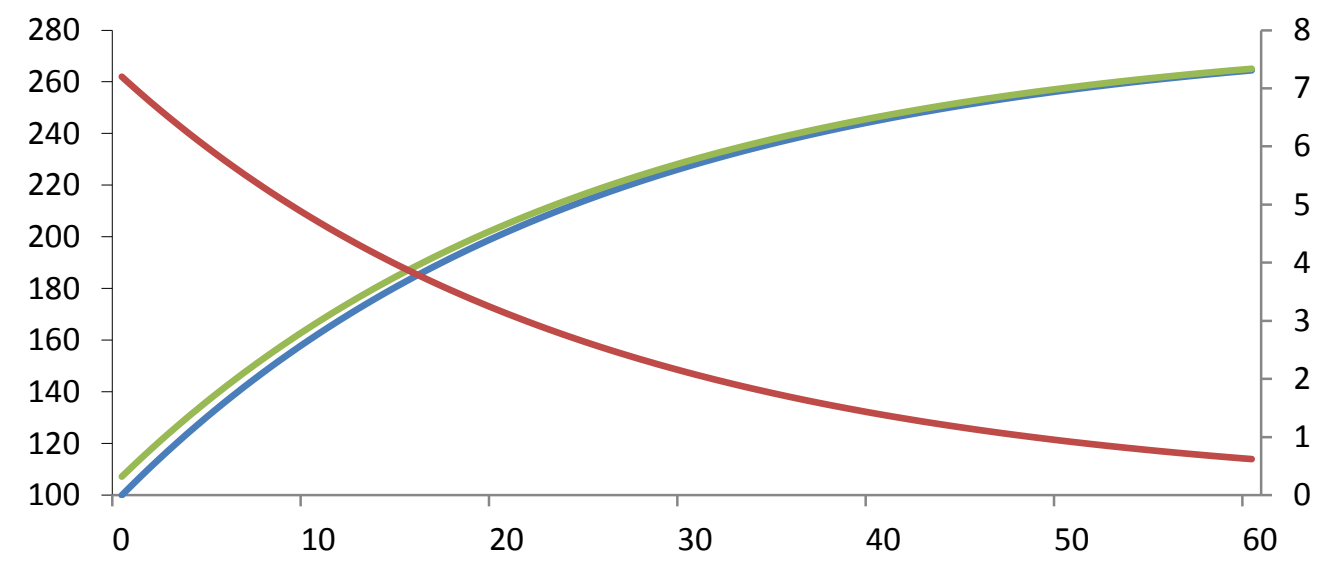

(a) Convergence to stationary state

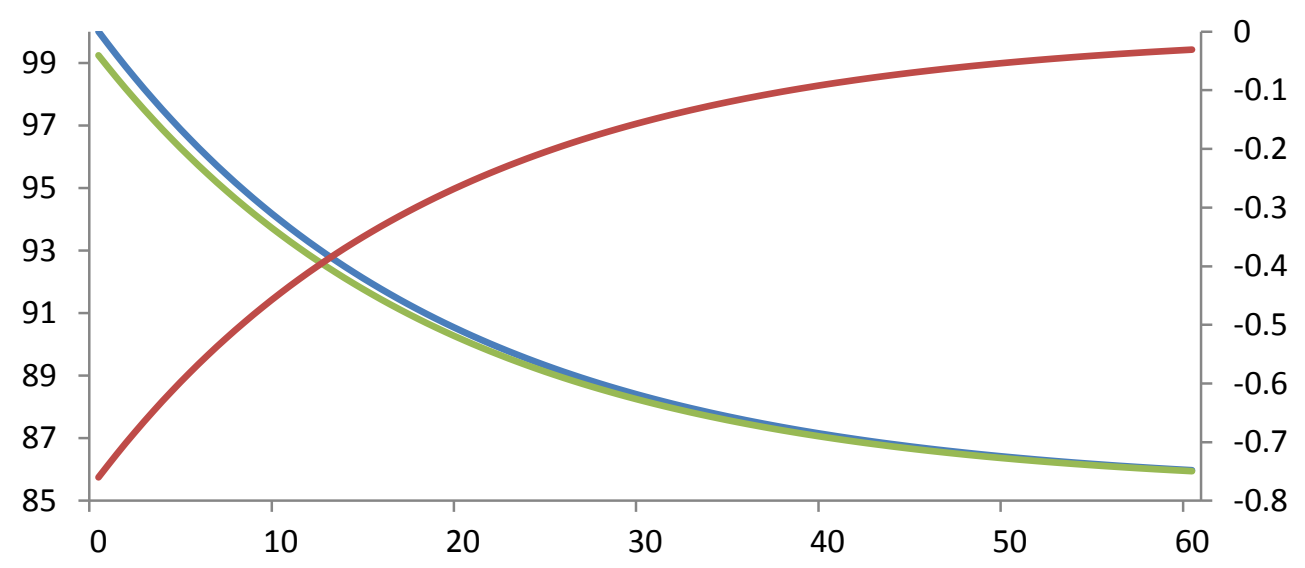

(b) Recession to stationary state

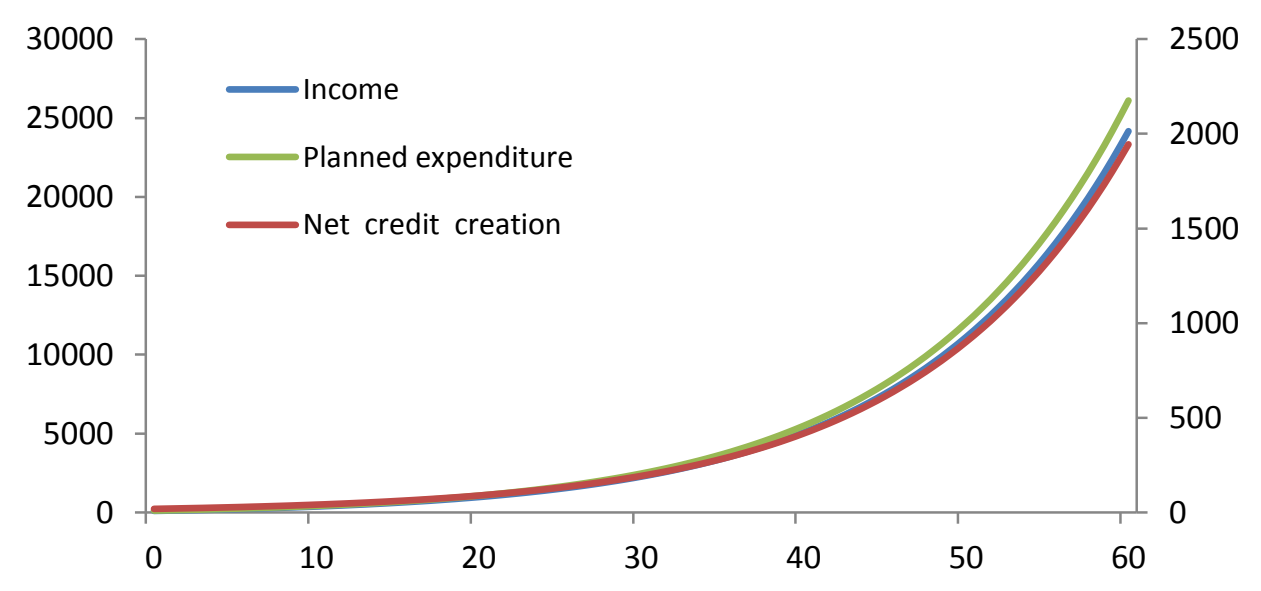

(c) Exponential growth 
Finally, Figure $4 \mathrm{c}$ models the case in which, due to a higher propensity to invest $(\eta=2)$ and a longer time to repay the debt $(\rho=15)$, the economy is able to expand forever on a balanced growth path. Net credit creation, equal to the wedge between planned expenditure and current income, continuously expands, ensuring a stable growth process.

The numerical simulations in all the three cases clearly show that both Krugman and Keen propositions are simultaneously realized in our model. That is, in each time $t$ income $Y$ is always equal to aggregate expenditure, respecting ex-post accounting consistency, and at the same time different from the expected aggregate expenditure, a variable that better represents Keen's definition of aggregate demand. The difference between income and expected expenditure is always equal to the net change in the stock of debt, as Keen argues:

$$
A D_{t}^{p}=Y_{t}+N C C_{t}
$$

\section{THE FULLY CONSISTENT MODEL}

Although the model presented in Section 3 can stand as a small macroeconomic model per se, we now add a second set of equations to make it stock-flow consistent. Stockflow consistent (SFC) models are increasingly used in modern macroeconomic theory, especially in order to analyze monetary and financial variables (Godley and Lavoie, 2012; Yamaguchi, 2013). This family of models makes extensive use of double entry accounting methodology, depicting each sector as a set of interacting assets and liabilities. At the end of every period assets must be equal to liabilities plus the net worth and, as a consequence, total changes in assets must be equal to the total change in liabilities.

Five sectors populate our model's economy: households, non-financial firms, private banks, a central bank and gilt sellers. Their balance sheets are described in Table 2. We also report the balance sheet matrix and the stock-flow matrix, in Tables 3 and 4 respectively, to show the stock-flow consistency of the model. 
Table 2: Assets and Liabilities

\begin{tabular}{|c|c|c|}
\hline Sector & Assets & Liabilities \\
\hline Households & Deposits $\left(\mathrm{D}_{\mathrm{hh}}\right)$ & Loans (L) \\
\hline Non-Financial Firms & $\begin{array}{c}\text { Deposits }(\mathrm{Df}) \\
\text { Capital }(\mathrm{K})\end{array}$ & Deposits (D) \\
\hline Private Banks & $\begin{array}{c}\text { Reserves }(\mathrm{R}) \\
\text { Loans }(\mathrm{L})\end{array}$ & Reserves (R) \\
\hline Central Bank & Bonds $\left(B_{c b}\right)$ & \\
\hline Gilts Sellers & Bonds $\left(B_{g s}\right)$ & \\
\hline
\end{tabular}

\subsection{Households}

We model households as having bank deposits $D_{h h}$ as their only asset, and no liabilities. The stock of deposits owned by households is equal to:

$$
D_{h h, t+1}=D_{h h, t}+W_{t}+C_{h h, t}
$$

where $C_{h h}$ is households' consumption. Given Equations (6) and (13), we can define $C_{h h}$ as:

$$
C_{h h, t+1}=W_{t}
$$

The equation above tells us that in each period t households consume an amount of goods equal to the previous period wage, on which they based their planned consumption. In a context of growth this will lead to an increase in the stock of deposits $D_{h h, t}$, as households consumption $C_{h h, t}$ is lower than households (expanding) income $W_{t}$ for each period t.

As it already appeared from Section 3 in our model households play a limited role, as their inability to borrow prevents them contributing to the expansion of aggregate demand. Consumption levels change, but they follow the economic dynamics rather than driving it. It would be relatively straightforward to relax this assumption to allow for a demand for loans from households, replicating the same framework we use for non-financial firms. 
Table 3: Balance sheet matrix

\begin{tabular}{|c|c|c|c|c|c|c|}
\hline & Household & $\begin{array}{c}\text { Non- } \\
\text { Financial } \\
\text { Firms } \\
\end{array}$ & Banks & $\begin{array}{c}\text { Central } \\
\text { Bank } \\
\end{array}$ & $\begin{array}{c}\text { Gilt } \\
\text { sellers }\end{array}$ & Total \\
\hline $\begin{array}{l}\text { Loans } \\
\text { Capital } \\
\text { Reserves } \\
\text { Gilts } \\
\text { Deposits } \\
\text { Net Worth }\end{array}$ & $\begin{array}{c}+\mathrm{D}_{\mathrm{hh}} \\
-\mathrm{NW}_{\mathrm{hh}}\end{array}$ & $\begin{array}{c}+\mathrm{D}_{\mathrm{f}} \\
-\mathrm{NW}_{\mathrm{f}}\end{array}$ & $\begin{array}{l}+\mathrm{L} \\
+\mathrm{R} \\
-\mathrm{D}\end{array}$ & $\begin{array}{l}-\mathrm{R} \\
+\mathrm{B}\end{array}$ & $\begin{aligned} & -\mathrm{B} \\
+ & +\mathrm{D}_{\mathrm{gs}}\end{aligned}$ & $\begin{array}{c}0 \\
+\mathrm{K} \\
0 \\
0 \\
0 \\
-\mathrm{NW}\end{array}$ \\
\hline Total & 0 & 0 & 0 & 0 & 0 & 0 \\
\hline
\end{tabular}

\subsection{Non-financial firms}

Non-financial firms have two kinds of assets - bank deposits $\left(D_{f}\right)$ and physical capital $(K)$ - and one liability - loans $(L)$. Bank deposits at time t are equal to:

$$
D_{f, t+1}=D_{f, t}+Y_{t}+C C_{t}-W_{t}-D R_{t}-Z_{t}-I_{t}
$$

In every period $t$ the stock of firms deposits is replenished by the revenues coming from selling the output and the new bank-created credit; simultaneously the stock is employed to pay wages, repay a proportion $1 / \rho$ of debt together with interest, and invest in new physical capital ${ }^{4}$.

Assuming no depreciation, the dynamics of the stock of physical capital are given by:

$$
K_{t+1}=K_{t}+I_{t}
$$

Finally, the dynamics of the stock of loans that appear on the liability side of nonfinancial firms' balance sheet - the debit owed to private banks - is given by Equation (15).

\footnotetext{
${ }^{4}$ In other words, the existence of a single good in the economy allows the new credit, together with firms net profits, to be turned instantaneously into capital
} 
Table 4: Flows of Funds Matrix

\begin{tabular}{|c|c|c|c|c|c|c|c|c|}
\hline & Households & $\begin{array}{c}\text { Firms } \\
\text { (Current) }\end{array}$ & $\begin{array}{c}\text { Firms } \\
\text { (Capital) }\end{array}$ & $\begin{array}{c}\text { Banks } \\
\text { (Current) }\end{array}$ & $\begin{array}{c}\text { Banks } \\
\text { (Capital) }\end{array}$ & $\begin{array}{c}\text { Central } \\
\text { Bank } \\
\text { (Capital) }\end{array}$ & $\begin{array}{c}\text { Gilts } \\
\text { Sellers } \\
\text { (Capital) }\end{array}$ & Tot \\
\hline $\begin{array}{l}\text { Consumption } \\
\text { Investment }\end{array}$ & $-\mathrm{C}_{\mathrm{hh}}$ & $\begin{array}{l}+\mathrm{C} \\
+\mathrm{I}\end{array}$ & $-\mathrm{I}$ & $-C_{b}$ & & & & $\begin{array}{l}0 \\
0\end{array}$ \\
\hline Wages & \multirow{3}{*}{$+\mathrm{W}$} & $-\mathrm{W}$ & \multirow{5}{*}{$+\Pi^{\mathrm{n}}$} & \multirow{5}{*}{$+\mathrm{Z}$} & \multirow[b]{5}{*}{$+\mathrm{CC}$} & \multirow{9}{*}{$\begin{array}{l}+\Delta \mathrm{R} \\
-\Delta \mathrm{B}\end{array}$} & \multirow{9}{*}{$\begin{array}{c}+\Delta \mathrm{B} \\
-\Delta \mathrm{D}_{\mathrm{gs}}\end{array}$} & 0 \\
\hline $\begin{array}{l}\text { Interest } \\
\text { payment }\end{array}$ & & $-Z$ & & & & & & 0 \\
\hline Net profits & & $-\Pi^{\mathrm{n}}$ & & & & & & 0 \\
\hline Savings & \multirow{5}{*}{$+\mathrm{S}_{\mathrm{hh}}$} & $+\mathrm{S}_{\mathrm{f}}$ & & & & & & 0 \\
\hline $\begin{array}{l}\text { Credit } \\
\text { creation }\end{array}$ & & $-\mathrm{CC}$ & & & & & & 0 \\
\hline Loans & & & \multirow[t]{4}{*}{$+\Delta \mathrm{L}$} & & \multirow{3}{*}{$\begin{array}{l}-\Delta \mathrm{L} \\
-\Delta \mathrm{R}\end{array}$} & & & 0 \\
\hline Reserves & & & & & & & & 0 \\
\hline Gilts & & & & & & & & 0 \\
\hline \multirow[t]{2}{*}{ Deposits } & $+\Delta \mathrm{D}_{\mathrm{hh}}$ & $-\Delta D_{f}$ & & & $+\Delta \mathrm{D}$ & & & 0 \\
\hline & 0 & 0 & 0 & 0 & 0 & 0 & 0 & 0 \\
\hline
\end{tabular}

\subsection{Private Banks}

Private banks have two kinds of assets: reserves at the central bank and loans, whose dynamics are described by Equations 33 and 15, respectively. Banks also have one liability, the total amount of deposits. Deposits at time $t$ are equal to:

$$
D_{t+1}=D_{t}+\Delta D_{h h, t}+\Delta D_{f, t}+\Delta D_{g s, t}
$$

where $\Delta D_{h h, t}, \Delta D_{f, t}$, and $\Delta D_{g s, t}$ represent the change in deposit of households, non-financial firms and gilts sellers, respectively.

\subsection{Central Bank}

The balance sheet of central bank is made of one asset - gilts $B_{c b}$ - and one liability reserves (R). Reserves are an account that private banks have at the central bank. The central bank in our model alters the amount of reserves and gilts according to the requests coming from the private banking sector. The stock of reserves is thus equal to:

$$
R_{t+1}=R_{t}+r\left(C C_{t}-D R_{t}\right)
$$

where $r$ is the so called reserve ratio, i.e. the required or voluntary proportion of deposits that private banks back with central bank reserves. Equation (33) simply states that the central bank will create or destroy an amount of reserves equal to a proportion $r$ of net credit creation by private banks. 
In order to have a balance between assets and liabilities the central bank buys or sells the same amount of bonds in the secondary market as follows:

$$
B_{c b, t+1}=B_{c b, t}+r\left(C C_{t}-D R_{t}\right)
$$

\subsection{Gilt sellers}

In our model gilt sellers are a sort of "ghost" agent representing the secondary market of gilts to which the central bank sells, or from which the central bank buys, the amount of gilts required by the chosen monetary policy. In the real economic system this role is typically played by pension funds. Gilt sellers simply respond to the requests of the central bank. We also assume that there is an infinite amount of gilts already available in the market in order to avoid the situation in which the secondary market is completely dried up.

\begin{tabular}{|c|c|c|c|}
\hline Shock name & Parameter affected & Initial value & Shock value \\
\hline Banks confidence & $\beta$ & 0.8 & 0.5 \\
\hline Animal spirits & $\eta$ & 1.5 & 1.9 \\
\hline Interest rate easing & $i$ & $5 \%$ & $1 \%$ \\
\hline Profits expansion & $\Pi$ & 0.7 & 0.6 \\
\hline Faster repayment & $\rho$ & 10 & 7 \\
\hline
\end{tabular}

Gilts sellers have two kinds of assets, banks deposits $D_{g s}$ and bonds $B_{g s}$, and no liability. If net credit creation is positive gilt sellers sell a quantity of bonds to the central bank equal to a proportion $r$ of the net credit creation: their stock of deposits increases and their stock of gilts decreases for the same amount. The opposite happens in case net credit creation is negative. The dynamics of deposits and gilts are described by the following equations:

$$
\begin{aligned}
& D_{g s, t+1}=D_{g s, t}+r\left(C C_{t}-D R_{t}\right) \\
& B_{g s, t+1}=B_{t}+r\left(D R_{t}-C C_{t}\right)
\end{aligned}
$$

\section{SCENARIO ANALYSIS}

We now test how our model reacts to changes in some of the relevant parameters. We will use the convergence to stationary state scenario (Scenario 1 in Table 1) as our business-as-usual (BAU) case. As it can be seen in Figure 5a, income growth rate in 
the default scenario is approximately equal to $7 \%$ at the beginning of the simulation and then slows down, reaching a value close to zero at its end (period 60). In the rest of the graphs (Figure 5b-5f) we report the difference between income growth rate in the shock scenario and the BAU scenario. We impose the shock at $\mathrm{t}=20$.

The set of scenarios we investigate is the following:

1. Banks confidence shock. A sudden drop in parameter $\beta$ mimics the case of an unforeseen shock in the confidence level of the banking system, which reduces its willingness to satisfy the demand for loans from the productive sector. We aim at replicating the strong decline in the loans approval rate experienced after the financial crisis (see Figure 2) by changing $\beta$ from 0.8 to 0.5 , meaning that banks will satisfy only $50 \%$ of demand for loans $L^{d}$ instead of $80 \%$. The exogenous shock leads to a drop in credit creation $C C$, which becomes lower than debt repayment $D R$, thus causing net credit creation $N C C$ to become negative. In other words, a shock in banks confidence causes planned expenditures to become lower than current income, triggering a recession (Figure 5b). Unless the confidence level is somehow restored, the growth rate converges to zero in the long run leading the economy to a new, lower, stationary state.

2. Animal spirits. In this case we model a positive shock in firms' propensity to invest $\eta$, in the attempt to grasp a sudden change in entrepreneurs "animal spirits". ${ }^{5}$ Parameter $\eta$ jumps from 1.5 - its default value - to 1.9 , meaning that the desired investment of firms $I^{d}$ are now 1.9 times their net profits $\Pi^{n}$. As it might be expected, the effect on income growth rate is positive (Figure 5c). In this case the increase in $\eta$ is strong enough to move the system on the exponential growth path (that is, $\eta>\eta_{g}$ ). The desire to invest more than the current level of profit is thus the most important growth driving force in our model.

3. Interest rate easing. We now impose a shock in the reference interest rate $i$, which passes from $5 \%$ to $1 \%$. This is very similar to what have happened in the aftermath of the crisis, where the central banks of developed countries have strongly cut their interest rate, currently very close to the zero lower bound. Consistent with their hopes, our model responds to the shock with an increase in the growth rate (Figure 5d), although a very limited one. A cut in interest rates by

\footnotetext{
${ }^{5}$ Keynes (1936) defined "animal spirits" as "a spontaneous urge to action rather than inaction".
} 
itself doesn't appear to be able to increase the long-run growth perspective of the economy, as the income growth rate gradually converges back to zero.

4. Profits expansion. Figure 5e reports the reaction of the model to a shock in the parameter representing the share of income going to labour, $\alpha$. The economy growth rate lurches upwards, indicating that economic expansion in our model is clearly profit-led. This shouldn't come as a surprise. Given the theoretical structure of our simple model, in which firms are the only economic agents able to borrow and a positive net creation of credit is the only manner to expand output, a higher proportion of income going to profits means, other things being equal, an increase in investments and, consequently, aggregate demand. As in the "animal spirits" scenario the shock is strong enough to move the system into the exponential trajectory. The growth rate converges to a long-run value higher than zero.

5. Faster repayment. Finally, we model the case in which the number of periods needed to repay the stock of debt, $\rho$, is decreased. This reflects the banking system's preference for shorter loans, although in the real economy this would most likely be a gradual shift rather than a sudden drop. The effect on growth is strongly negative, as the flow of debt repayment becomes larger than the newly created credit, thus leading planned expenditure to be lower than current income. 
Figure 5: Income growth rate (difference w.r.t. BAU in figures 5b-5f)

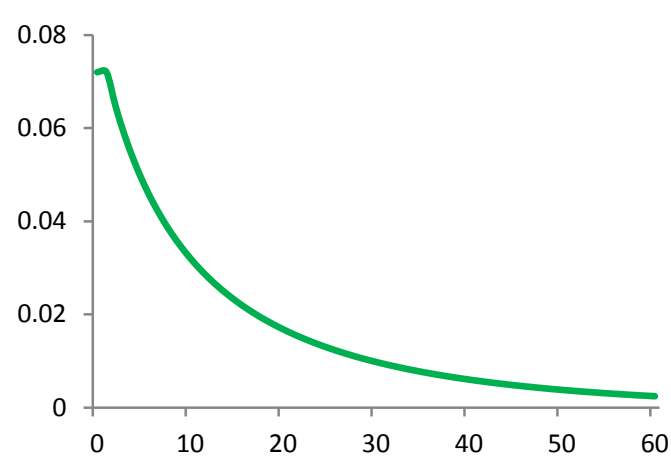

(a) Default scenario

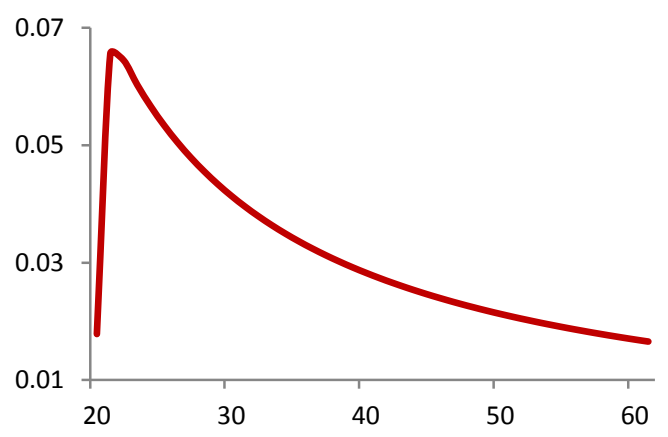

(c) Animal spirits

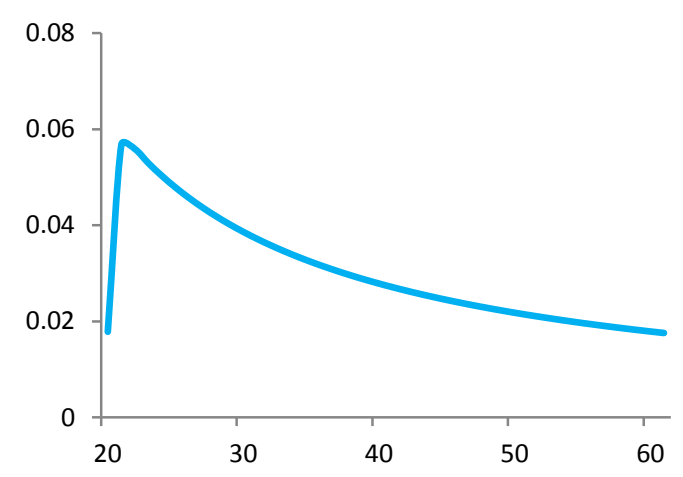

(f) Profits expansion

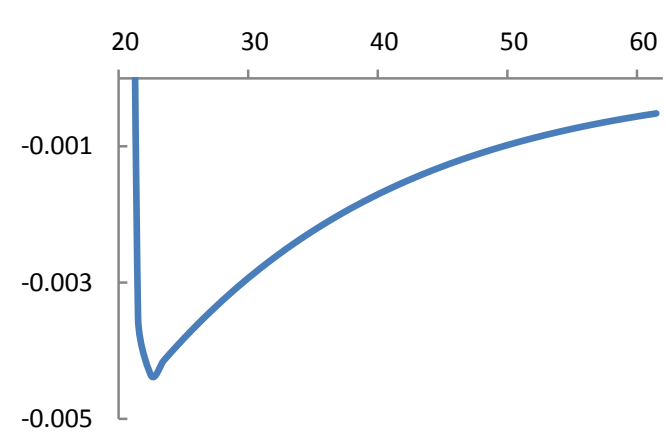

(b) Banks confidence shock

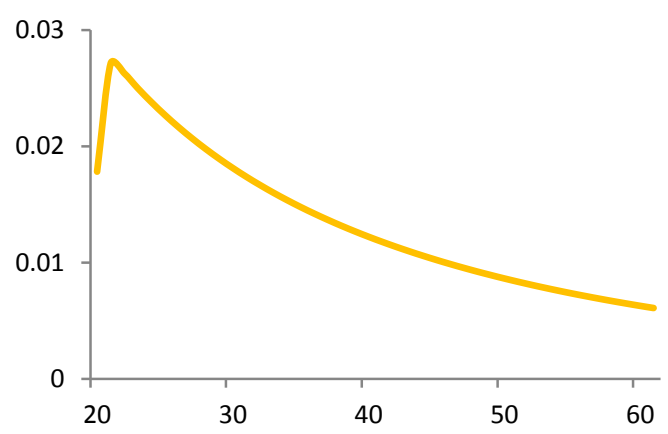

(d) Interest rate easing

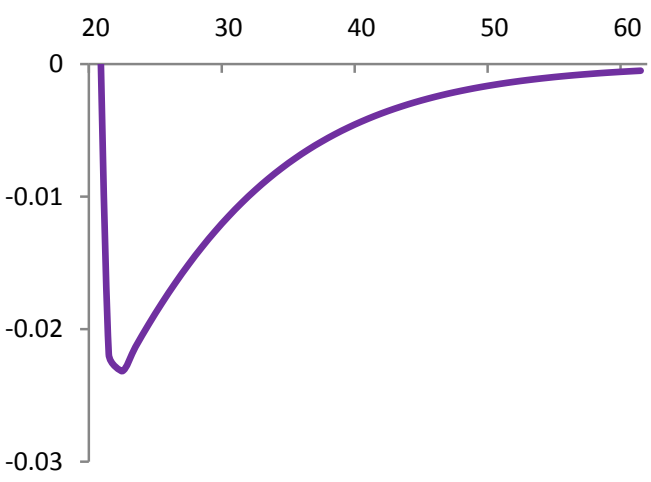

(g) Faster repayment 


\section{CONCLUSION AND FUTURE RESEARCH}

In this paper we presented a simple and original analysis of the mechanisms through which the banking system affects the functioning of the macroeconomic system, focusing in particular on the ability of private banks to autonomously create new credit for the productive sector. In our model growth is driven by the existence of a gap between the current income levels of firms and their future expenditure plans, which is filled thanks to the credit that the banking system is willing to create for them. A confident banking system, willing to grant credit to firms for productive investments, is a necessary prerequisite for the economy to prosper.

The model is composed of a "core" dynamic unit and a set of sectoral accounts representing the agents populating the economy: households, non-financial firms, private banks, the central bank and gilt-sellers. The dynamic unit is a small model per se, although not consistent from a stock-flow perspective. We showed, both analytically and through numerical simulations, that the model can be characterized by two different long-run dynamics, one leading to a stationary state and the other to a balanced growth path. The firms' propensity to invest and the willingness of the banking system to concede credit appear to be the most crucial parameters in determining which dynamic will govern the system. The set of sectoral accounts is instead not relevant in terms of the dynamics, but ensures the model's stock-flow consistency. For this reason each agent is built using a double-entry bookkeeping methodology.

Finally, we argued that our paper contributes in an original way to the literature on the subject. The model can be seen as an analytical representation of the idea, of which Hyman Minsky was the main creator, that in order to grow an economic system has to have expenditure plans higher than its current income. This was the same idea at the center of the debate between Keen and Krugman in 2012, to which we offered a plausible "solution".

The model presented here is characterized by a range of limiting assumptions and simplifications, of which we feel the most notable is the exogenous nature of some crucial parameters. In particular, important insights could be obtained by making propensity to invest $\eta$ and banks confidence $\beta$ endogenous and defining them as some function of - for instance - the profit rate, or the economy's growth rate, or the ratio of 
debt to GDP. The probable result would be to enrich the dynamics of the system through cycles and higher instability.

The reason why we preferred to keep them exogenous is that we were here aiming at clarifying the very essential mechanisms of an economic process - the process of credit creation by private banks - which is quite surprisingly still marginal to mainstream economic theory and obscure to many. Giving a functional form to our key parameters would have meant following particular theories on investment decisions and banking behavior, with the risk of becoming too specific, and most likely wrong.

In keeping the theoretical structure simple we have instead been able to describe the process of credit creation with reasonable certainty and highlight some important economic relations valid at all times. Although firms' decisions on how much to invest are certainly a function of some other variables in the real economy, investments will by definition be some proportion of firms' income, which is here represented by parameter $\eta$. In a similar way, newly created credit will by definition be equal to some proportion of the demand for loans, here represented by $\beta$. This "accounting" methodology in our view allows us to grasp some crucial features of the functioning of banking systems and their influence on modern economies.

As for potential future research, the most fruitful direction that we envisage is, after having modeled the process of creation of credit by banks, to study the process of allocation of such credit. The strong aggregation of the model presented here doesn't allow this kind of analysis, but to whom the credit is allocated matters in real economic systems. Creating credit for small and medium enterprises in the industrial sector shapes the economy in a very different way than allocating credit to - for instance - financial firms.

The model could thus be expanded by introducing an allocation choice by the banking system. An interesting distinction could be the one between "productive" and "speculative" sectors, where the main difference between the two is that the former contributes to GDP while the latter doesn't (Werner, 2005; Ryan-Collins et al., 2012). Or, alternatively, the same theoretical structure could be employed to sketch the dynamics of the transition to a low-carbon society, thus assuming a choice of credit allocation between "green" and "dirty" industries.

This topic clearly also has strong policy implications. The lack of credit to the productive sectors is seen as the major obstacle to a full economic recovery after the 
crisis and many central bank operations, such as the quantitative easing measures, have been designed to stimulate the creation of new credit by private banks. The results of such interventions have been mixed, and this has led many to study alternative proposals to make the central bank liquidity flow to firms in a more direct fashion. We intend to develop this research stream in the next steps of our work. 


\section{REFERENCES}

Bank of England. (2012a). "The Framework for the Bank of England's Operations in the Sterling Money Markets." Red Book, Bank of England. (2012b). Speech given by Mervyn King, Governor of the Bank of England, to the South Wales Chamber of Commerce, 23 October 2012.

Benes, J. and M. Kumhof. (2012). "The Chicago Plan Revisited.” IMF Working Paper WP/12/02, International Monetary Fund.

Bernardo, G. and E. Campiglio. (2012). Reconciling Krugman and Keen: An Analysis of the Relation between Debt and Aggregate Demand Using nef Model. Presentation available at http://www.slideshare.net/emacampiglio/reconcilingkrugman-and-keen-using-nef-model.

Berry, S., R. Harrison, R. Thomas, and I. De Weymarn. (2007). Interpreting Movements in Broad Money. Quarterly Bulletin - Bank of England , 376-388.

Bezemer, D. (2009). "No One Saw This Coming: Understanding Financial Crisis through Accounting Models." Munich Personal RePEc Archive Paper No. 15892.

Bezemer, D., M. Grasselli, M. Hudson, and S. Keen. (2012). Endogenous Money and Effective Demand. Available at http://debunkingeconomics.com/wpcontent/uploads/2012/10/TowardsUnificationMonetaryMacroeconomicsMath Argument.pdf.

Binswanger, M. (2009). "Is There a Growth Imperative in Capitalist Economies? A Circular Flow Perspective." Journal of Post Keynesian Economics. 31, 707727.

BIS (2011). "BIS Small Business Survey.” Technical Report, UK Department for Business, Innovation \& Skill.

Blanchard, O. and D. Johnson (2012). Macroeconomics. Prentice Hall.

Brayton, F. and P. Tinsley (1996). "A Guide to FRB/US. A Macroeconomic Model of the United States." Technical Report, Federal Reserve.

Caverzasi, E. and A. Godin (2013). "Stock-flow Consistent Modeling through the Ages.” Working paper No. 745, Annandale-on-Hudson, NY: Levy Economics Institute of Bard College.

Dieppe, A., A. Pandiella, and A. Willman (2011). "The ECB's New Multi-Country Model of the Euro Area: NMCM - Simulated with Rational Expectations." ECB Working paper No. 1315, European Central Bank.

Godley, W. and M. Lavoie (2012). Monetary Economics: An Integrated Approach to Credit, Money, Income, Production and Wealth. Palgrave Macmillan.

Godley, W. and G. Zezza (2006). "Debt and Lending." Economics Policy Note Archive 06-4, Annandale-on-Hudson, NY: Levy Economics Institute of Bard 


\section{College.}

Goodhart, C. (1984). Monetary Theory and Practice: The UK Experience. Palgrave Macmillan.

Harrison, R., K. Nikolov, M. Quinn, G. Ramsay, A. Scott, and R. Thomas (2005).

“The Bank of England Quarterly Model.” Technical Report, Bank of England.

Keen, S. (1995). "Modeling Minsky's 'Financial instability hypothesis"'. Journal of Post Keynesian Economics. 17, 607-635.

(2001). Debunking Economics: The Naked Emperor of the Social Sciences. Pluto Press Australia.

—. (2012). "Instability in Financial Markets: Sources and Remedies." Available at http://ineteconomics.org/sites/inet.civicactions.net/files/keen-steve-berlinpaper.pdf.

Keynes, J. M. (1936). The General Theory of Employment, Interest and Money. London: Palgrave Macmillan.

Lavoie, M. (2003). “A Primer on Endogenous Credit-Money.” In L. P. Rochon and S. Rossi (Eds.), Modern Theories of Money: The Nature and Role of Money in Capitalist Economies. pp. 506-543. Edward Elgar Publishing.

Lavoie, M. and W. Godley (2001-2002). "Kaleckian Models of Growth in a Coherent Stock-flow Monetary Framework: A Kaldorian View." Journal of Post Keynesian Economics. 24 , 277-311.

Minsky, H. P. (1982). Can "It" Happen Again?: Essays on Instability and Finance. Armonk, N.Y.: M.E. Sharpe.

Moore, B. J. (1988). Horizontalists and Verticalists: The Macroeconomics of Credit Money. Cambridge: Cambridge University Press.

O'Sullivan, K. and S. Kinsella (2011). “An Institutional Architecture for Meta-Risk Regulation in Irish Banking. Lessons from Anglo Irish Bank's Minsky Moment." Journal of Banking Regulation. 12, 342-355.

Romer, R. (2000). "Keynesian Macroeconomics without the LM curve.” Journal of Economic Perspectives. 14, 149-169.

Ryan-Collins, J., T. Greenham, R. Werner, and A. Jackson (2012). Where Does Money Come From? New Economics Foundation, London.

Schumpeter, J. A. (1934). The Theory of Economic Development: An Inquiry into Profits, Capital, Credit, Interest and the Business Cycle. Cambridge, Massachusetts: Harvard University Press.

Werner, R. (2005). New Paradigm in Macroeconomics. Palgrave Macmillan.

Yamaguchi, K. (2013). Money and Macroeconomic Dynamics - Accounting System Dynamics Approach. New version 1.0. http://www.muratopia.org/JFRC/sd/yamaguchi.html 


\section{A. APPENDIX}

\section{A.1 Derivation of Eigenvalues}

Looking at system (16)-(17) it's easy to see that the matrix of coefficients is equal to where:

$$
\begin{gathered}
a_{11} \quad a_{12} \\
a_{11}-1 \quad a_{12}+1 \\
a_{11}=1-\frac{1+\beta(\eta-1)(1+i \rho)}{\rho} \text { and } a_{12}=-\frac{1+\beta(\eta-1)(1+i \rho)}{\rho}
\end{gathered}
$$

The eigenvalues of the system $\lambda_{1}$ and $\lambda_{2}$ are the solutions of the equation:

$$
\lambda^{2}-\lambda\left(a_{11}+a_{12}+1\right)+a_{11}+a_{12}=0
$$

It's easy to see that $\lambda=1$ is always a solution of (A.1). The other root can be found using an alternative form for the characteristic equation:

$$
(\lambda-1)(\lambda-\chi)=\lambda^{2}-(1-\chi) \lambda+\chi=0
$$

where 1 and $x$ are the equation solutions. Comparing (A.1) and (A.2) it's easy to conclude that:

$$
\chi=\lambda_{2}=a_{11}+a_{12}
$$

\section{A.2 Derivation of Equation (21)}

Using $l_{t} \equiv \frac{L_{t}}{Y_{t}}$ one can reformulate system (16)-(17) as:

$$
\begin{aligned}
& l_{t+1}\left(1+g_{y}\right)=\left\{1-\frac{1+\beta(\eta-1)(1-i \rho)}{\rho}\right\} l_{t}+\beta(1-\alpha)(\eta-1) \\
& 1+g_{y}=-\frac{1+\beta(\eta-1)(1+i \rho)}{\rho} l_{t}+[1+\beta(1-\alpha)(\eta-1)]
\end{aligned}
$$

where $g_{Y}=\frac{Y_{t}-Y_{t-1}}{Y_{t-1}}$ is the growth rate of income Y.

Substituting (A.5) in (A.4\}) one obtains:

$$
\left(a_{11}-1\right) l^{2}+\left(1+a_{12}-a_{11}\right) l-a_{12}=0
$$


By finding the roots of (A.6) one obtains (21).

\section{A.3 Dynamics of the System}

The peculiar shape of system (16)-(17) presented in Appendix A.1, and in particular the presence of an eigenvalue always equal to 1, creates a slightly unusual dynamics, which is shown in Figure A.1. The two stable arms for which $\Delta \mathrm{L}$ and $\Delta \mathrm{Y}$ are equal to zero lie one on top of the other, and also coincide with the eigenvector associated with the eigenvalue equal to 1 . The eigenvector associated to the other eigenvalue, which can be higher or lower than 1 depending on the numerical values assigned to parameters, determines whether the system falls into the stationary state case (Figure A.1a) or the exponential growth case (Figure A.1b).

Figure A.1: Phaseplanes of the system

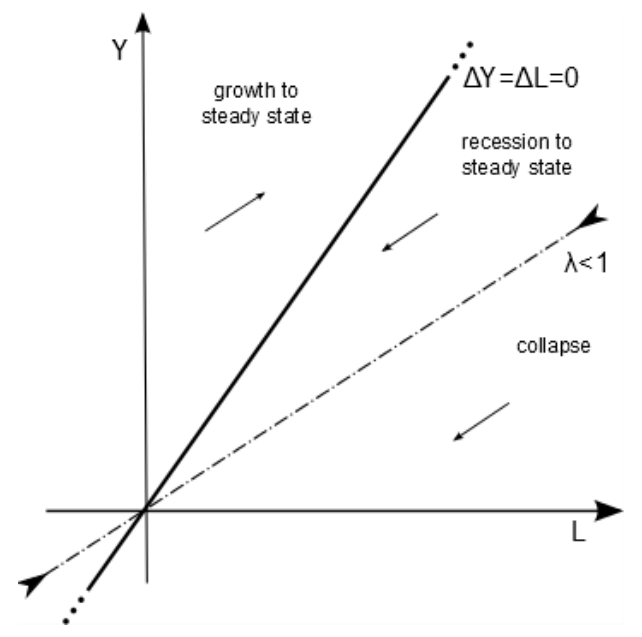

(a) Stationary state case

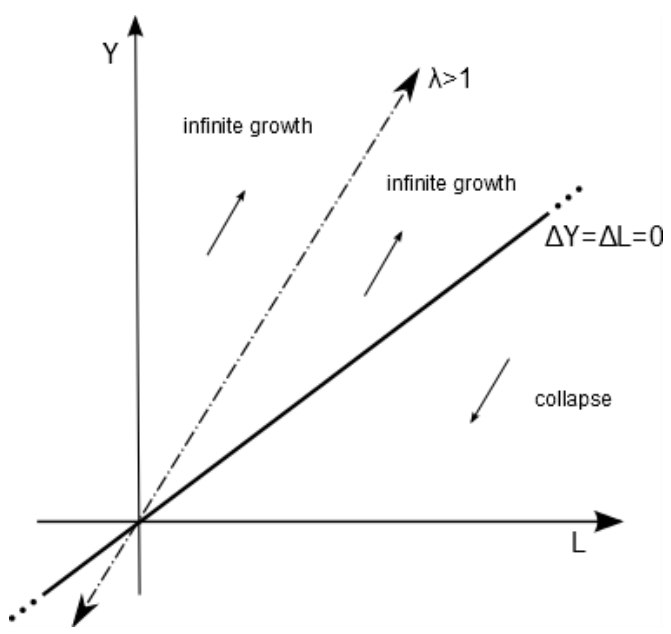

(b) Exponential growth rate 